Journal of Balkumari College

ISSN : 2467-9321 Website: http://www.nepjol.info/index.php/jbkc

Volume : 9, Issue : 1, June 2020, Page No.: 89-94

\title{
Corporate Social Responsibility on Firms' Financial Performance: Evidence of Banking Sectors of Nepal
}

\author{
Sudip Wagle* \\ Lecturer \\ Birendra Multiple Campus \\ Research Scholar \\ DDU Gorakhpur University
}

\begin{abstract}
The purpose of this study was to find the trend and relationship of Corporate Social Responsibility (CSR) practices and Firm's Financial Performance of Commercial Banks in Nepal. CSR became a mandatory issued in Nepal. Based on gaps in the extant literature, the current study hypothesizes that three dependent variables of financial performance i.e. Return on Assets (ROA), Return on Equity (ROE) and Net Income (NI) on the independent variable CSR. Out of listed 27 Commercial banks, the sample includes only 3 banks for the base of extensively disclosing CSR activities, from earlier than issued mandatory laws in Nepal. Four years of data (2015/16 to 2018/19) were collected for the study purposes. Data analyzed and interpreted using Statistical Package for Social Science (SPSS) Specifically Pearson's Correlation to analysis the relationship between CSR disclosure activities and Financial Performance. The results revealed that out of 3 variables only a CSR activity on ROA is significantly accepted with having a negative correlation among them. Moreover, CSR activity on ROE \& CSR activity on NI both are insignificant, having a neutral relationship i.e. rejected.
\end{abstract}

Key Words: CSR, Mandatory, ROA, ROE, NI, Financial Performance, Nepal

\section{INTRODUCTION}

The concept of Corporate Social Responsibility (CSR) emphasizes on the corporate duties to social and environmental practices. Nepal is a developing country, its initiation discussion on CSR dimension has still viewed as immature nation (Adhikari et al., 2016). It has a long history of unsound government; the nation is facing problems in so many sectors. The concept of CSR been changed now and again proportionately as to the changing needs of business and society. CSR and profit maximization are the interrelated goals of the firm (Chapagain \& Phil, 2012). The strategic approach has decidedly related to the company and its stakeholders (Pant \& Piansoongnern, 2017). In this situation, business enterprises can play effective CSR role to improve their reputation just as long- term financial goals by improving social welfare as a whole.

Despite the extensive studies on CSR most are concentrated on status review, practices of CSR disclosure, attitude towards CSR by stakeholders and CSR related activities by companies in the context of Nepal. In any case, no any adequate examination conducted dependent on CSR and Financial Performance. Most of the Nepalese companies aside from banking sectors did not mention CSR explicitly on their sites (Wagle, n.d.). Thus, this study is to explore the relationship between CSR and Financial Performance of banking sectors as post obligatory in Nepal.

\section{LITERATURE REVIEW}

\section{Corporate Social Responsibility (CSR)}

Corporate Social Responsibility (CSR) implies that a corporation should consider responsible for any of its actions that influence people, communities and the environment. As indicated by (McWilliams \& Siegel, 2000), CSR is set of all those activities not forced by the law of those countries. The business has become the most powerful

* Corresponding author: sudip.wagle@gmail.com 
institution on earth for the last 50 years. The dominant institution in any society needs to take responsibility for the entirety. Each decision has made by each action that saw considering sort of responsibility (Lin et al., 2009). Business leaders believed that business had a responsibility to society that to worked with their endeavors to make benefits (Acquier et al., 2011).

\section{Financial Performance (FP)}

Financial Performance is a mix of the financial situation along with an association's capacity to meet its business policy compulsions and commitment (Ernst Juerg Weber, 2015). As indicated by (Marshall, 2013), FP expressed as an act of undertaking financial activities. However, in the more extensive sense; FP identifies with how much financial or monetary destinations been acknowledged by an element. Besides, FP is the way toward checking the monetary accomplishments of business issues by implementing policies and strategies at a particular point in time. In this regard, there are a number of accounting and market base measurements including return on assets (ROA), return on equity (ROE), earning per share (EPS), net income or profit (NI), operating profit (OP) and gross profit (GP).

\section{Relationship between CSR and FP}

The relationship between CSR and FP found three schools of thought (positive, negative or neutral) from the literature (Ullmann, 1985). Return on Assets (ROA) and Return on Equity (ROE) are the most consistently used as dependent variables in CSR financial performance (Tang, Hull \& Rothenberg, 2012).

\section{Corporate Social Responsibility (CSR) in Nepal}

As indicated by (Pant \& Piansoongnern, 2017), the strategic approach to CSR can assist the companies with gaining support to betterment in financial performance. Management of Nepalese firm still is engaged in maximum profit thought process as opposed to social interest (Shah, 2013). These days, Companies were increasingly positive towards CSR and stakeholders management. The attitude towards CSR by banking and manufacturing sectors managers were positive by favorable public image and negative by cost including pricing structure with assured about CSR and profit maximization for common goals of the firm (Chapagain \& Phil, 2012). According to (Kandel, 2018) focused that the sectors by the company concern their CSR activities and the relation of CSR on financial performance. The relationship of CSR with the financial performance of the company results was positive (93.33\%), negative $(0 \%)$ and indifferent $(6.67 \%)$ respectively. It seems that the most of the employees believe that CSR contributes to financial performance. As indicated by (Wagle, n.d.) contemplate the CSR reporting trend and focusing areas of CSR intervention by the Nepalese Companies. Out of 3 sectors ( 3 commercial bank, 1 insurance and 1 hotel) of selected companies, Multiple times reporting information was caught from the banking sites since establishment. However, scarcely 3 equivalent time reporting information was caught from remaining two sectors of companies. Companies relate most of the CSR areas of intervention involved to environmental awareness, blood donation and donation to bridhasharma, is $80 \%$. In addition, $60 \%$ intervene in healthcare and furthermore, support to equipment installation for social security, a donation to various food item for orphanage and donation to the school is $40 \%$.

As indicated by (Ohdgv et al., n.d.) Out of the 14 different types of banks point outs that only $71.43 \%$ of them are reporting about their CSR activities. Besides, most of the CSR areas of intervention concerned are related to education/training $64.29 \%$, contribution to the welfare of underprivileged $64.29 \%$, arts/heritage/culture, associations/clubs/trusts/organization, and healthcare for $42.86 \%$ each and so forth. This result shows that when CSR is not obligatory in Nepal, few banks had already taken CSR practices as an involuntary basis also some have CSR report page on their sites. According to (Adhikari et al., 2016) they had together given the exploration on Corporate Social Responsibility domains analyzing from focus group discussion. According to this study, out of 21 statements of the discussion, the most elevated 10 statements pursued by representing economic domains. 9 statements followed by philanthropic, 8 ethical and 6 legal domains. Among them, few domains activities are overlapping. The findings conclude that the strategic importance of CSR activities is getting higher in Nepal. Similarly, (Journal \& Arts, 2017) exposed research on both structured Questionnaire and focus group discussion. 
The methods are Questionnaire to faculty members of Tribhuvan University those who have been teaching over 5 years and focus group discussion to different background experts like industry and academia. The result enhancing corporate reputation is the first benefits of adopting CSR activities in an organization. Likewise, to improve employee's institution and community, efficiency increment, acquisition of commercial benefits and identification of reputational risks as second, third, fourth and fifth respectively. In addition, to test the perception towards CSR, among 16 discussion statement findings shows that, it was not time to being CSR as a mandatory in Nepal due to very low condition of legitimate and ethical domains. However, the awareness of the positive attitude of corporations towards CSR activities has strategically being changed.

\section{Hypothesis}

1. H1: CSR activities have a significant positive relationship with NI.

2. H2: CSR activities have a significant positive relationship with ROA.

3. H3: CSR activities have a significant positive relationship with ROE.

\section{METHODOLOGY}

The nature of the study is quantitative. A regression/correlation research design has embraced to evaluate the degree of relationship between CSR and Financial Performance. Out of 27 listed commercial banks in Nepal, only 3 banks (Citizens Bank International, Nepal Bangladesh Bank and Everest Bank) were chosen as a sample for 4 years period ( 2015/16 to 2018/19) by using purposive sampling method (only those banks which clearly mention their CSR contribution i.e. expenses \& activities disclosure in their annual reports). According to the nature of study following econometric model has applied to test the hypothesis:

$\mathrm{FP}=\beta 0+\mathrm{CSR}+\varepsilon$

To simplicity, the regression equation divided into three equations respective to each proxy of FP.
a. $\quad \mathrm{NI}=\beta \mathrm{o}+\beta 1 \mathrm{CSR}+\varepsilon \quad$ (1a)
b. $\quad \mathrm{ROA}=\beta \mathrm{o}+\beta 1 \mathrm{CSR}+\varepsilon(1 \mathrm{~b})$
c. $\quad \mathrm{ROE}=\beta \mathrm{o}+\beta 1 \mathrm{CSR}+\varepsilon(1 \mathrm{c})$

Where FP represents Financial Performance, NI represents net income, ROA represents a return on assets and ROE represents a return on equity have been taken as proxies of dependent variable whereas CSR corporate social responsibility represents as independent variable. Furthermore, $\varepsilon$ is serving as an error terms in the equation of the study.

\section{RESULTS AND DISCUSSION}

The results of overall descriptive statistics and correlation matrix between independent variable (CSR) and three dependent variables of firm performance (NI, ROA \& ROE) have shown in the following table.

Table 1

Relationship between NI \& CSR

\begin{tabular}{ccccccc}
\hline & Model & Sum of Squares & df & Mean Square & F & Sig. \\
\hline 1 & Regression & 3225.456 & 1 & 3225.456 & .010 & $.923^{\text {b }}$ \\
& Residual & 3284369.729 & 10 & 328436.973 & & \\
Total & 3287595.185 & 11 & & & \\
\hline
\end{tabular}

Source: Based on Secondary Data

Table 1 shows that the relation between NI and CSR is not significant (.923) that the value is greater than the p-value (.05) suggesting, NI as far as its impact by CSR is concerned. 


\section{Table 2}

Relationship between ROA \& CSR

\begin{tabular}{ccccccc}
\hline & Model & Sum of Squares & df & Mean Square & F & Sig. \\
\hline 1 & Regression & .427 & 1 & .427 & 9.199 & $.013^{\mathrm{b}}$ \\
& Residual & .464 & 10 & .046 & & \\
& Total & .890 & 11 & & & \\
\hline
\end{tabular}

Source: Based on Secondary Data

From table 2 it seen that the relation between ROA and CSR is significant (.013) that the value is less than p-value (.05) suggesting, ROA as close as its impact by CSR is concerned. This results is supported the empirical study from (Okoye et al., 2017) that the relationship between four CSR activities (environmental, community, marketplace \& workplace) with financial performance (ROA \& ROE) were positive. Their findings reveal that CSR has a significant impact on ROE \& ROA as financial performance. In the same line, (Lin et al., 2009) and (Nyongesa, 2017) findings that significant positive impact on ROA only on long term period but no significant impact on ROA in a short-term period.

Table 3

Relationship between ROE \& CSR

\begin{tabular}{lllllll}
\hline Model & & Sum of Squares & df & Mean Square & F & Sig. \\
\hline \multirow{3}{*}{1} & Regression & .289 & 1 & .289 & .014 & $.907^{\mathrm{b}}$ \\
& Residual & 199.327 & 10 & 19.933 & & \\
& Total & 199.616 & 11 & & & \\
\hline
\end{tabular}

Source: Based on Secondary Data

Above table 3 shows that the relation between ROE and CSR is not significant (.907) that the value is greater than p-value (.05) suggesting, ROE as far as its impact by CSR is concerned. The results are in confirmation with previous studies, similar to (Isanzu \& Fengju, 2016) and (Iqbal et al., 2012) studies concluded that there is no significant relationship between CSR and Firm's financial performance i.e. both ROA and ROE.

Table 4

Aggregate Regression Coefficient Table

\begin{tabular}{ccccccc}
\hline Model & & Un standardized Coefficients (B) & $\mathrm{T}$ & $\mathrm{P}$-Value & $\mathrm{R}$ & $\mathrm{R}^{2}$ \\
\hline 1a (NI) & (Constant) & 1355.80 & 4.644 & .001 & $.031^{\mathrm{a}}$ & .001 \\
& CSR & .352 & .099 & .923 & & \\
$1 \mathrm{~b}(\mathrm{ROA})$ & (Constant) & 2.132 & 19.438 & .000 & $.692^{\mathrm{a}}$ & .479 \\
& CSR & -.004 & -3.033 & .013 & & \\
$1 \mathrm{c}(\mathrm{ROE})$ & (Constant) & 15.808 & 6.950 & .000 & $.038^{\mathrm{a}}$ & .001 \\
& CSR & .003 & .120 & .907 & & \\
\hline
\end{tabular}

Source: Based from Secondary Data

The above table 4 shows that, $\beta$ value and its impact of CSR on NI, ROA \& ROE. CSR on NI and CSR on ROE, $\beta$ value (.352), (.003) are in a positive direction that means for every unit increase in CSR Financial Performance i.e. NI \& ROE also increases with $0.352 \& 0.003$ respectively and also p-value is above than standard $(.923>.05),(907>.05)$. Therefore, it demonstrates that there is a neutral relationship and statistically insignificant impact between the variables. Thus, alternative hypothesis 1 and 3 both are rejected. Besides this, CSR on ROA, $\beta$ value (-.004) is in a negative direction that means for every unit increase in CSR Financial Performance i.e ROA decreases by -0.004 and $p$-value is less than standard $(.013<.05)$. Therefore, it found that there is a negative 
relationship but statistically significant impact of CSR on ROA. Thus, alternative hypothesis 2 is accepted.

Table 5

Correlations

\begin{tabular}{ccccc}
\hline & CSR & NI & ROA & ROE \\
\hline CSR & 1 & & & \\
NI & .031 & 1 & & \\
ROA & $-.692 *$ & -.253 & 1 & \\
ROE & .038 & .092 & .073 & 1 \\
\hline
\end{tabular}

*Correlation is significant at the 0.05 level (2-tailed).

Table 5 represents the degrees of relationship between NI, ROA and ROE. The reported results shows that there is a negative correlation between CSR and ROA ( $\mathrm{r}=-.692$, p value is less than .05) is significant. Moreover, CSR to NI, CSR to ROE have positive relationship ( $\mathrm{r}=.031)$, $(\mathrm{r}=.038)$ but statistically insignificant in results. This study conclusion is similar to (Maqbool \& Zameer, 2018) and (Yang et al., 2010) that among the financial performance measurement tools (ROA, ROE, EPS) in their findings also only CSR to ROA is significant with the positive relationship but CSR to ROE \& CSR to EPS both are insignificant.

\section{CONCLUSION}

In order to find the pattern \& relationship of CSR on Firm's Financial Performance, researcher has chosen commercial banks based on most elevated CSR disclosure of activities. The data extracted from annual reports, using the quantitative methods from the period of 2015/16 to 2018/19. Out of three hypothesis only one (CSR on ROA) is significantly accepted with a negative relationship. Further hypotheses (CSR on NI \& CSR on ROE) are insignificant with neutral relationship i.e they are rejected. Banks has allocated and exposed CSR reserve fund as directives from NRB in their annual reports however they weren't able to utilized such fund in a proper way because corporations are confused from the directives where and how to do CSR activities. At this point, they are in a state of wait and see. Such situation shows that their yearly cumulative fund is greater than their yearly expenditure. The relationship between CSR on NI and CSR on ROE were likewise positive. That shows great positive signals for mandatory CSR practices in upcoming days in Nepal that will be revealing in both the business and society.

\section{REFERENCES}

Acquier, A., Gond, J. P., \& Pasquero, J. (2011). Rediscovering howard r. bowen's legacy: The unachieved agenda and continuing relevance of social responsibilities of the businessman. Business and Society, 50(4), 607-646. https://doi.org/10.1177/0007650311419251

Adhikari, D. R., Gautam, D. K., \& Chaudhari, M. K. (2016). Corporate social responsibility domains and related activities in Nepalese companies. International Journal of Law and Management, 58(6), 673-684. https://doi.org/10.1108/IJLMA-08-2015-0044

Chapagain, B. R., \& Phil, M. (2012). Corporate Social Responsibility : a Review of Managers 'Attitudes in Nepal 1. July 2013, 1-5.

Ernst Juerg Weber. (2015). ECONOMICS A Short History of Derivative Security Markets By Ernst Juerg Weber The University of Western Australia.

Iqbal, N., Ahmad, N., Basheer, N.A., \& Nadeem, M. (2012). Impact of Corporate Social Responsibility on Financial Performance of Corporations: Evidence from Pakistan. International Journal of Learning and Development, 2(6), 107-118. https://doi.org/10.5296/ijld.v2i6.2717

Isanzu, J., \& Fengju, X. (2016). Impact of Corporate Social Responsibility on Firm's Financial Performance: The Tanzanian Perspective. Journal on Innovation and Sustainability. RISUS ISSN 2179-3565, 7(1), 18. https://doi.org/10.24212/2179-3565.2016v7i1p18-27 
Journal, N., \& Arts, O. F. (2017). Research Review Corporate Social Responsibility in Nepal : Is Csr Doing Good for Business and Society? 66-74.

Kandel, L. R. (2018). Corporate Social Responsibility in Nepalese Commercial Bank with reference to Bank of Kathmandu Limited. NCC Journal, 3(1), 90-99. https://doi.org/10.3126/nccj.v3i1.20251

Lin, C. H., Yang, H. L., \& Liou, D. Y. (2009). The impact of corporate social responsibility on financial performance: Evidence from business in Taiwan. Technology in Society, 31(1), 56-63. https://doi. org/10.1016/j.techsoc.2008.10.004

Maqbool, S., \& Zameer, M. N. (2018). Corporate social responsibility and financial performance: An empirical analysis of Indian banks. Future Business Journal, 4(1), 84-93. https://doi.org/10.1016/j. fbj.2017.12.002

Marshall. (2013). On principles of economy. In Journal of Chemical Information and Modeling (Vol. 53, Issue 9). https://doi.org/10.1017/CBO9781107415324.004

McWilliams, A., \& Siegel, D. (2000). Corporate Social Responsibility and Financial Performance: Correlation or Misspecification? Author ( s ): Abagail McWilliams and Donald Siegel Published by: Wiley Stable URL : http://www.jstor.org/stable/3094143 Accessed : 03-05-2016 07 : 02 UTC CORPOR. Strategic Management Journal, 21(5), 603-609. https://doi.org/10.1002/(SICI)1097$\underline{0266(200005) 21}$

Nyongesa, W. R. (2017). Corporate Social Responsibility and Financial Performance: The Case of Safaricom Ltd. International Journal of Finance and Accounting, 6(6), 167-171. https://doi. org/10.5923/j.ijfa.20170606.02

Ohdgv, U., Wkh, W. R., Ri, G., Frqfhsw, W. K. H., \& Dv, O. (n.d.). csr IN nepali banks.

Okoye, L. U., Modebe, N. J., \& Ahmed, A. (2017). Corporate Social Responsibility and the Financial Performance of Deposit Money Banks in Nigeria. Journal of Policy and Development Studies, 11(3), 30-39. https://doi.org/10.12816/0040640

Pant, D. R., \& Piansoongnern, O. (2017). Impact of Corporate Social Responsibility on Sustainable Competitive Advantage: A Case Study of Leading Noodle Companies in Nepal. International Journal of Social Sciences and Management, 4(4), 275-283. https://doi.org/10.3126/ijssm.v4i4.17940

Shah, K. K. (2013). Corporate Social Responsibility in Nepal. Academic Voices: A Multidisciplinary Journal, 2, 33-37. https://doi.org/10.3126/av.v2i1.8283

Tang, Z., Hull, C. E., \& Rothenberg, S. (2012). How Corporate Social Responsibility Engagement Strategy Moderates the CSR-Financial Performance Relationship. Journal of Management Studies, 49(7), 1274-1303. https://doi.org/10.1111/j.1467-6486.2012.01068.x

Ullmann, A. A. (1985). Data in Search of a Theory: A Critical Examination of the Relationships Among Social Performance, Social Disclosure, and Economic Performance of U.S. Firms. Academy of Management Review, 10(3), 540-557. https://doi.org/10.5465/amr.1985.4278989

Wagle, S. (n.d.). Corporate Social Responsibility : A Status Review of Nepalese Selected Companies. 1-11.

Yang, F., Lin, C., \& Chang, Y. (2010). The linkage between corporate social performance and corporate financial performance. African Journal of Business Management, 4(4), 406-413. 